\title{
ARMADILHAS DA HONRA E DO PERDÃO: USOS SOCIAIS DO DIREITO NA MATA PERNAMBUCANA
}

Lygia Sigaud

Por ocasião do golpe de Estado de 1964, os militares desencadearam operações de repressão sistemática contra os que haviam participado ativamente das lutas sociais. Foi o que ocorreu na zona canavieira de Pernambuco, onde desde os anos 50, com as Ligas Camponesas, e do início da década de 60 , com os recém-criados sindicatos de trabalhadores rurais, tinha havido enfrentamentos com os donos de terra, greves e grandes manifestações pelo cumprimento dos direitos trabal histas recém-estendidos aos homens do campo. Em Rio Formoso, município do litoral sul da mata pernambucana, o sindicato foi invadido e fechado: os dirigentes sindicais que não conseguiram escapar foram presos; outros desapareceram sem deixar rastros; os delegados sindicais tornaram-se alvo de perseguição policial e/ou militar, após serem denunciados pelos patrões, fossem eles senhores de engenho ou usineiros. Foi nesse contexto que A maro Pedro, delegado sindical do engenho 1 Porto A legre, sentindo-se em perigo, pediu a proteção do patrão do engenho Amaragi, que tinha reputação de ser um homem "bom". J osé Bezerra - este era seu nome - acoIheu A maro Pedro em suas terras, como um de seus moradores, como eram denominados aqueles que residiam e trabal havam nas plantações.

Passados alguns meses do golpe, graças à mediação de padres da Igreja Católica junto aos militares², os sindicatos foram reabertos e começaram a se reestruturar. As greves e manifestações pelo cumprimento dos direitos eram impensáveis na nova conjuntura. Os militares, no entanto, mantiveram a J ustiça em funcionamento e não revogaram o Estatuto do Trabalhador Rural, a lei votada pelo Congresso Nacional em 1963 estendendo a legislação trabal hista ao campo. Os dirigentes sindicais empenharam-se então em estimular os moradores a encaminharem reclamações à J ustiça do Trabalho, com base na nova lei. Tendo retomado seus contatos com o sindicato, Amaro Pedro apresentou, no ano de 1965, uma 
queixa contra J osé Bezerra, na J unta de Conciliação e J ulgamento do município de Escada, pelo não pagamento de alguns encargos trabalhistas. O patrão mal pôde acreditar ao receber a intimação judicial. Mandou chamar o morador, que confirmou ser ele quem o estava processando.

No dia da audiência, ambos se encontraram diante do juiz. Bezerra foi condenado e pagou sua dívida na J unta. De volta a Amaragi, mandou o administrador dizer a A maro Pedro que não queria mais vê-lo e nem que o cumprimentasse. Na manhã seguinte, o trabalhador foi ao encontro do patrão na casa-grande: com lágrimas nos olhos pediu-lhe perdão e lhe devolveu o dinheiro ganho na véspera. $E$ a paz se restabeleceu entre eles.

Foi J osé Bezerra o primeiro a me relatar este episódio. Em 1995, encontrei-o em A maragi. Tinha então 74 anos. M orava no engenho e já estava aposentado. A gestão da fazenda havia delegado a Roberto, seu único filho. Quase no final de uma entrevista que tratava de sua trajetória ${ }^{3}$, o vel ho patrão narrou o episódio envolvendo A maro Pedro e, invertendo os papéis, perguntou-me: "Como a senhora explica isso? Porque eu, eu nunca entendi". Passados trinta anos, o fato ainda o intrigava. Na véspera mesmo, disse-me, havia rememorado o acontecimento com o administrador da fazenda.

Em 1996, Bezerra faleceu. No ano seguinte, encontrei-me com Amaro Pedro, então com 74 anos. Estava aposentado e desde 1988 não morava mais no engenho. Instalara-se em uma pequena casa na cidade de Rio Formoso, mantendo em A maragi seu sítio, aos cuidados da filha mais veIha. A história me foi então recontada com outros detalhes. $\mathrm{Na}$ saída da audiência, ele teria se dado conta de seu ato: "M as o que foi que eu fiz com o seu Zé Bezerra?" Procurou então o patrão, que lhe disse: "Vá trabalhar. Não vou odiá-lo nem botá-lo pra fora". Processar Bezerra foi uma "fraqueza de juízo", contou-me um ainda arrependido A maro Pedro, que nunca mais recorreu à J ustiça contra seu patrão - e chorou sua morte.

$\mathrm{O}$ acolhimento de um delegado sindical pelo patrão em um momento turbulento como o pós-64, o episódio do processo, o pedido e a concessão do perdão são fatos que podem ser classificados como excepcionais no âmbito das relações sociais das plantações canavieiras. Tradicionalmente, os patrões abrigavam pessoas a eles ligadas que porventura estivessem sendo perseguidas por inimigos ou pela Polícia. Esta tendia a respeitar a autoridade dos senhores de terra e não entrava nos engenhos. Não era, no entanto, esperado que viessem a acolher aqueles que colocavam em questão a ordem social e política nas plantações, como o estavam fazendo, no início dos anos 60 , sindical istas e delegados sindicais. Processar o patrão por violação dos direitos era ainda prática incipiente 
entre os trabalhadores rurais no ano seguinte ao golpe. Mas tanto naquele momento como nos anos subseqüentes, quando a prática se generalizou, não se esperaria que aquele que, ao ser amparado pelo patrão, com ele contraíra uma dívida moral, fosse lhe acusar na J ustiça: dívidas morais tendem a anular dívidas jurídicas. Procurar ser perdoado depois de ter movido um processo é recorrente na zona canavieira. $O$ arrependimento, entretanto, manifesta-se na seqüência do ato de dar queixa e não após a audiência, que ocorre já passado algum tempo, três meses no mínimo. Conceder o perdão a alguém que foi até o fim nos trâmites judiciais é uma questão que nem sequer se coloca: normal mente, os patrões respondem aos que reclamam na J ustiça com represálias.

Casos excepcionais, ou os chamados casos contrários, como esse envolvendo Bezerra e A maro Pedro, têm a virtude de expor à luz aquilo que permanece à sombra nas anál ises centradas sobre as normas e construídas por meio de modelos que, ao não atentarem para aquilo que neles não se encaixa, terminam por produzir visões simplificadas e empobrecedoras do mundo social, como se o seu funcionamento fosse simples e mecânico, como se na realidade as coisas não fossem fluidas, como insistiam Max Weber e Edmund Leach (cf. Leach 1961; Weber 1965). M as os casos contrários só se tornam reveladores quando examinados no âmbito das configurações sociohistóricas precisas em que ocorreram. É o que proponho fazer aqui : vou tratar de reconstituir as condições sociais nas quais se produziu o caso Bezerra-A maro Pedro, de recuperar o sentido que tiveram suas condutas na sucessão dos eventos, de identificar as coerções que se abateram sobre eles e explorar as implicações do acontecimento. Em um segundo momento, vou examinar a história das relações sociais no engenho Amaragi no período que se segue ao processo, tendo como foco o direito, seus usos e sua eficácia. $O$ interesse em proceder a esta análise reside na possibilidade de melhor compreender não só as condições sociais nas quais o direito, após a promul gação do Estatuto do Trabalhador Rural, se tornou um regulador das relações sociais nas plantações canavieiras, como também a dinâmica e a complexidade do processo que contribuiu para que os indivíduos passassem a agir levando em conta a existência das normas jurídicas ${ }^{4}$.

\section{A chegada dos direitos}

J osé Bezerra era natural de Vitória de Santo Antão, município situado no oeste da zona canavieira. Filho mais velho de um senhor de engenho, 
chegou a Rio Formoso em 1952, com 32 anos, para arrendar Amaragi, de propriedade da Usina Central Barreiros. Carlos, seu irmão, veio na mesma época e tornou-se arrendatário de outra propriedade da mesma usina, o engenho Serra d'Água. Eles eram dois, dentre 22 herdeiros, e sua saída da casa paterna certamente teve relação com as chances mínimas que tinham de ali lograrem vir a também se tornar senhores de engenho. O início da década de 50 foi um momento de expansão da produção de cana-de-açúcar, graças a uma conjuntura internacional favorável que abria novos mercados à produção brasileira. A Usina Central Barreiros colocava em marcha uma política de pleno aproveitamento de seu patrimônio fundiário: as terras entregues aos dois irmãos eram então praticamente inexploradas. Cabia a eles ali desenvolver a agricultura da cana e, segundo os termos do contrato de aluguel, vender a produção, após a coIheita, à usina. Desde o início da colonização, o açúcar era fabricado nos engenhos; foi apenas a partir do século $X X$ que a sua produção passou a ser feita, de forma centralizada, nas usinas então criadas5. J á a agricultura da cana seguia sendo praticada nos engenhos, fossem ele explorados pelos industriais do açúcar, pel os grandes proprietários ou pelos rendeiros, como eram conhecidos os que arrendavam terras.

Em Amaragi, Bezerra encontrou apenas alguns homens e ele precisava de muitos mais para explorar um engenho de 1.200 hectares: a produção da cana era feita - e ainda hoje o é - com grandes contingentes de mão-de-obra. Com os que lá se encontravam e as centenas de outros que fez vir, Bezerra reproduziu o mesmo tipo de relações sociais que conhecia desde a infância no engenho do pai: as relações de morada ${ }^{6}$. No quadro da morada, o patrão estabelecia um laço pessoal com cada um de seus moradores. $O$ homem que quisesse trabalhar em um engenho se dirigia ao patrão para Ihe pedir morada. Esta compreendia uma casa, o direito de cultivar um pedaço de terra para sua própria subsistência e uma remuneração pelo trabalho efetuado na plantação. Aquele que se tornava um morador sabia que poderia contar com o patrão, que o protegeria, sobretudo nos momentos difíceis, como em caso de doença e morte; ele sabia também que o patrão Ihe daria presentes, como roupas no $\mathrm{N}$ atal, peixe na Páscoa e, eventualmente, carne fresca. Em contrapartida, ele deveria trabalhar apenas para o seu patrão e Ihe ser leal. Tais coisas não eram ditas no momento do pedido e concessão da morada, e tampouco algum documento era assinado. Tudo era implícito e todos conheciam as regras do jogo. J á nas usinas, o pedido da morada era dirigido ao administrador do engenho e as relações com o patrão eram mais impessoais. Contudo, no espaço dos engenhos de usinas, os industriais tinham igualmente a 
preocupação de respeitar al gumas das regras de morada, a fim de atrair moradores para as suas propriedades. Assim, também autorizavam os moradores a cultivar a terra e os amparavam em momentos difíceis, por meio dos serviços de proteção social que implantavam nas usinas?.

Do ponto de vista do observador, a proteção e os presentes constituíam obrigações patronais, assim como os deveres de não trabalhar fora e de ser leal correspondiam a obrigações dos moradores. Tratava-se de obrigações cuja garantia repousava em uma convenção e cuja legitimidade estava fundada na crença na tradição, retomando aqui as proposições weberianas ${ }^{8}$. Mas para o trabalhador apenas as suas obrigações eram percebidas enquanto tais. As do patrão ele as representava como dons, como sinais de sua bondade, e sentia-se, portanto, endividado. De sua parte, o patrão concebia-se como um doador: a casa de morada, a terra para cultivar, os presentes ao longo do ano atestavam apenas a sua generosidade. Ser generoso era um valor, e o prestígio dos patrões se media pelos sinais exteriores de sua magnanimidade9. Como nem todos os patrões desempenhavam suas obrigações do mesmo modo, havia aqueles que eram tidos como melhores que os outros. J osé Bezerra fez tudo para se comportar como "um bom patrão" e logrou ser assim reconhecido. Progressivamente, graças à sua reputação, foi atraindo trabalhadores para Amaragi e conseguiu a mão-de-obra de que necessitava.

A maro Pedro nasceu no engenho Canto Alegre, em Rio Formoso. Pertencia a uma família de moradores. A rigor, os moradores provinham sempre de famílias que, de geração em geração, se punham a serviço dos patrões da cana-de-açúcar. Sua mãe era originária de outro engenho Porto A legre - e tinha sido criada pela patroa na casa-grande. Não se conhece a origem de seu pai. Dele sabe-se apenas que tinha uma função qualificada: ocupava-se das bestas de carga, era estribeiro. Como costumava ocorrer com os trabalhadores qualificados, era disputado pelos patrões e tinha forte mobilidade profissional. Assim, durante a infância, A maro Pedro morou em vários engenhos. Em 1945, com 23 anos, ele encontrava-se no engenho onde sua mãe havia nascido e cujo dono acabara de falecer. A viúva, após delegar a gestão de Porto Alegre a seu filho, instalou-se no Recife, levando com ela Amaro Pedro, que era seu afilhado, e sua irmã: os pais deles também haviam falecido, e ela se sentia responsável por eles. Diz Amaro Pedro que a viúva os incentivou a estudar, mas que ele preferiu voltar para Rio Formoso. Em seu retorno, começou a circular pelos engenhos, como acontecia com freqüência entre os jovens celibatários, que não podiam legitimamente candidatar-se à morada, reservada aos chefes de família. Ele deslocou-se bastante, sempre por en- 
genhos particulares - como são nomeadas as plantações exploradas por um proprietário ou um arrendatário, para distingui-las daquelas exploradas pelos usineiros - e terminou por se reinstalar em Porto Alegre, onde se casou e se tornou morador.

Ora, desde o início dos anos 50, todo um conjunto de sinais indicava que estava em marcha uma mudança nas regras da morada. Os patrões começam a expandir o cultivo da cana e a buscar ganhos de produtividade. Para tanto, retiram dos moradores o usufruto das terras, de onde obtinham parte importante de sua subsistência, e modificam as formas de remuneração do trabalho feito. Além disso, passam a negligenciar suas obrigações de protetores e doadores. Essa ruptura unilateral das regras do jogo cria as condições de possibilidade da ruptura de outras regras que os moradores aceitavam como parte da ordem natural das coisas, notadamente aquelas que os obrigavam a serem leais a seus patrões e a não questionarem sua autoridade. Por volta de 1955, uma importante reação começa a se estruturar na região oeste da zona canavieira, com a constituição das Ligas Camponesas ${ }^{10}$.

Nos anos que se seguem, a reação dos moradores alastra-se pela mata pernambucana. Às Ligas vêm se somar sindicatos ${ }^{11}$, que começam a ser criados com o apoio de militantes comunistas, trotskistas, católicos de esquerda e de autoridades do governo federal interessadas em reduzir o poder dos grandes proprietários de terra12. No resto do país, amplia-se a organização dos trabalhadores do campo, com a formação de ligas, associações e sindicatos, e, com ela, a pressão pela regulamentação das relações de trabalho no campo e pela reforma agrária. É nessa conjuntura que é votado, em 1963, pelo Congresso Nacional, o Estatuto do TrabaIhador Rural, que impunha aos patrões numerosas obrigações e, em caso de conflito, a mediação da J ustiça trabal hista.

A extensão dos direitos sociais foi um evento de grande envergadura em Pernambuco. Nos dias que se seguiram à votação da lei, como assinala Furtado (1964), o respeito às novas normas jurídicas tornou-se um objeto de luta. As condições políticas eram favoráveis, graças à chegada de Miguel Arraes ao governo do estado. Eleito com o apoio de forças sociais ditas "progressistas", A rraes assegurou a liberdade de organização e de expressão na região das plantações. Os sindicatos promoviam greves e manifestações pelo pagamento dos novos direitos, sobretudo do salário mínimo e do 13o salário, e apoiavam os primeiros processos judiciais de moradores contra as violações dos direitos trabalhistas. Aqueles que nunca tinham ido à J ustiça contra seus patrões começaram a fazê-lo. Cinco tribunais trabalhistas foram então instalados na zona canavieira. Gra- 
ças à mediação do governador, o primeiro contrato coletivo de trabalho na história das relações sociais nas plantações foi, então, estabelecido entre os dirigentes sindicais dos patrões e os dos trabalhadores dos engenhos ${ }^{13:}$ ele previa, entre outras disposições, uma tabela definindo os preços e as dimensões das tarefas agrícolas, que constituíam o motivo mais recorrente de conflitos nos engenhos, uma vez que os patrões os impunham unilateralmente.

Em Amaragi, Bezerra procurou adaptar-se à nova conjuntura: assinou as carteiras de trabalho, passou a respeitar algumas das novas obrigações legais e não se opôs a que o sindicato promovesse a eleição de um delegado sindical entre seus moradores. Sua conduta era destoante em Rio Formoso, onde os patrões, como nos demais municípios da zona canavieira, reagiam à aplicação da lei e ao trabalho sindical. Os conflitos multiplicaram-se em torno do respeito aos direitos, termo que os trabaIhadores utilizavam para designar as novas obrigações impostas aos patrões e categoria carregada de simbolismo.

Em Porto Alegre, onde se encontrava Amaro Pedro, os companheiros de engenho e os dirigentes sindicais do município sugeriram que ele assumisse a função de delegado sindical, mas ele não aceitou. Como não sabia ler, Amaro Pedro achava que não estava à altura da missão. Seus amigos insistiram: para eles, Amaro Pedro, como ele próprio afirmava, tinha uma "boa cabeça", uma "boa teoria". Ele se dispôs então a ajudálos. E é bem como uma "ajuda" que expõe em seu relato o trabalho sindical no engenho e a tarefa de delegado sindical de fato. Os conflitos em Porto Alegre, como fora dali, estavam relacionados à extensão das tarefas agrícolas, nomeadas média, e à remuneração correspondente. Quando achavam a média exagerada, os moradores pediam a Amaro Pedro para que negociasse com o patrão. Se não houvesse acordo, ele recorria ao sindicato. Os dirigentes sindicais iam ao engenho. Em caso de impasse, ordenavam a greve. Havia também greves gerais, que mobilizavam os trabalhadores de todo o município, como as que ocorreram pelo pagamento do 13o salário.

Só Amaragi permanecia à margem do movimento social: lá não havia greves. Bezerra fazia reuniões semanais com os moradores para Ihes dizer que estava ao seu lado, que não tinham necessidade de fazer greves, conforme contou Zé Chico, o antigo dirigente sindical do engenho. Então, por "respeito" ou por "medo", afirmou ele, os moradores não faziam paralisações e eram, conseqüentemente, malvistos pelos outros trabalhadores do município. Em seu relato, trinta anos depois dos fatos, Bezerra ainda se orgulhava de nunca ter havido greve em seu engenho. Se- 
gundo ele, é porque ele era "bom". O argumento da "bondade", salientado por Bezerra, constitui uma espécie de doxa entre os moradores de A maragi e outros que viveram esse período: alguns chegaram a afirmar que o patrão "não merecia" uma greve.

\section{A caça aos "comunistas"}

Quando do golpe de Estado, o mundo desmoronou para os líderes sindicais. A maro Pedro foi denunciado por seu patrão como "comunista" e "agitador", as mais freqüentes acusações contra aqueles que haviam participado ativamente do movimento de protesto e reivindicação. A Polícia foi buscá-lo à noite, em Porto A legre, mas ele conseguiu escapar e "correr", em suas palavras, até A maragi. Foi ao encontro de Bezerra, a quem já conhecia.

A maragi era o engenho mais produtivo de Rio Formoso e, freqüentemente, faltavam-Ihe braços durante os períodos de colheita. Bezerra mandava buscar, com a autorização dos patrões, os trabalhadores dos engenhos onde o corte da cana já era findo. Foi nestas circunstâncias que A maro Pedro começou a freqüentar Amaragi: ia até lá para cortar cana. A ocasião era certamente privilegiada para que se certificasse de que era procedente a fama de Bezerra. Amaro Pedro sabia que aquele patrão ajudava muita gente em Porto A legre: transportava, em seu próprio carro, os doentes para hospitais de Rio Formoso e Barreiros, município vizinho. Bezerra já havia sido prefeito de Rio Formoso entre 1958 e 1962, eleito em uma disputa contra o candidato apoiado pelos donos de Cucaú, uma das usinas do município. Ainda que A maro Pedro não faça referência a esta gestão, é provável que tenha sido nessa época que Bezerra saiu em socorro da gente de Porto Alegre. Em Amaragi, ouviu pessoas que viviam sob a proteção de Bezerra dizerem que ele era um homem "bom". Além disso, viu com seus próprios ol hos sinais de uma "bondade" que certamente Ihe interessava mais: não havia restrições ao cultivo da terra pelos trabalhadores; muitos tinham sítios, verdadeiro ideal dos moradores e símbolo de uma relação mais durável com o patrão, como assinala Palmeira (1977b). No ato de dar um sítio já feito ou de autorizar o morador a fazê-lo em uma extensão de terra determinada, o patrão também dizia simbolicamente que o apreciava, que o queria bem e que desejava que ele ficasse. 0 morador se sentia mais seguro e mais livre para desenvolver a agricultura de subsistência e a criação de animais, para si mesmo e para sua família. Em Porto Alegre, Amaro Pedro habitava no arruado do 
engenho' ${ }^{14}$. Sua mulher criava cabras, porcos e galinhas, mas eles não tinham roçado ${ }^{15}$, não podiam possuir gado e não tinham expectativa de vir a ganhar um sítio.

Certo dia, Amaro Pedro conheceu Bezerra pessoalmente. Seu relato é cheio de detalhes. A pós o trabal ho em Amaragi, ao voltar a pé para casa, por um dos caminhos do engenho que desembocavam em Porto Alegre, cruzou com o patrão. Este estava acompanhado de um empregado, termo que designa tanto o administrador (o primeiro da hierarquia administrativa depois do patrão) quanto os cabos (os segundos). Amaro Pedro não precisa quem era esse empregado. Bezerra o cumprimentou - era normalmente educado com os moradores, o que nosso personagem assinala como uma das provas de que era "bom". Indagou onde Amaro Pedro morava, se tudo ia bem por lá, quais serviços sabia fazer. Estas eram as perguntas que os patrões costumavam fazer ao acolher um candidato à morada. Em seguida, Bezerra propôs a A maro Pedro que viesse morar com ele, em A maragi, dizendo-Ihe que poderia cultivar a terra e criar vacas para ter leite fresco todos os dias. Estava certamente ciente das proibições impostas pelo patrão de Porto A legre, e as referências à terra e às vacas podem ser interpretadas como um meio de seduzir Amaro Pedro. Ora, convidar alguém para se tornar morador não era corrente, cabendo antes ao trabalhador apresentar-se ao patrão para pedir morada. $\mathrm{O}$ fato de Bezerra convidar A maro Pedro não se pode explicar somente pela necessidade de mão-de-obra em A maragi. Não se acolhia qualquer um. $O$ mais provável é que Bezerra já houvesse tido referências a respeito das qualidades de A maro Pedro como trabalhador, possivelmente transmitidas pelos empregados, que estavam sempre em contato com a mão-deobra. Aquele que acompanhava o patrão deve ter sinalizado Amaro Pedro antes que se travasse o diálogo. Este último não disse não, mas tampouco aceitou a proposta. Pode-se aventar a hipótese de que ele preferiu permanecer em Porto Alegre para dar prosseguimento a suas atividades sindicais. Iniciadas as perseguições, era chegada a hora de ir para Amaragi.

Em seu relato dos eventos de abril de 1964, Bezerra diz que "esse homem" chegou com dois outros. A rigor, ele jamais pronunciou o nome de A maro Pedro, a quem se referia sempre como "esse homem" ou "o homem". Disse-me, como que me apresentando o personagem, que o homem não morava com ele, que era morador de um outro senhor de engenho. Bezerra acrescentou que o patrão era "um pouco perverso" com relação a A maro Pedro, que desejava botá-lo para fora e que o havia denunciado. De sua parte, já conhecia Amaro Pedro e o considerava um "homem bom". Segundo Bezerra, ele Ihe teria dito: 
“Seu Zé eu vim para o senhor me proteger, porque o senhor sabe, o senhor me conhece, sabe que eu não sou agitador. Eu não sou nada disso e seu fulano [o patrão de Porto Alegre] disse que eu era um agitador e a Polícia foi para me pegar e me matar no cacete. Eu consegui fugir, não sei minha família como está. Eu queria que o senhor mandasse vir a família para aqui para o engenho do senhor".

Bezerra respondeu:

“Olhe, você é um homem, eu conheço você, e sei que você não é disso. Mas você, de qualquer maneira está sendo perseguido pela Polícia. Se eu mandar Ihe buscar, em lugar de você ser perseguido, quem vai ser sou eu. Não é? Porque se tem um ladrão e você ampara e a Polícia vem e você não deixa que a Polícia tome... Você é que vai responder por aquilo".

Logo após esta conversa, autorizou os três a dormirem em A maragi. Os dois que acompanhavam A maro Pedro partiram na manhã seguinte, e Bezerra jamais os viu novamente. Uma semana depois, enviou um caminhão a Porto Alegre para trazer a família e as coisas "do homem". Neste mesmo dia, a Polícia foi a Amaragi procurar A maro Pedro, acusando Bezerra de abrigar um “agitador". Bezerra discutiu com a Polícia. Disse:

“Não, esse homem não é agitador. Quem vocês deveriam prender é o dono do engenho. Ele é que é agitador. M as o homem não. O homem é um homem pobre, indefeso. Vocês fizeram isso porque é um homem que não tem com que se defender. Por que não faz comigo? E vai fazer com um pobre desse, que merece todo o amparo de quem pode dar amparo".

O capitão (foi na verdade o Exército, e não a Polícia, que comandou a repressão) insistiu para que Bezerra mandasse buscar Amaro Pedro porque ia prendê-lo. O patrão respondeu que o capitão tinha poderes para Ihe dar tal ordem, mas ameaçou ao mesmo tempo: "O senhor pode ir [buscar A maro Pedro], porque o senhor é uma força superior a mim. Mas se o senhor for, eu vou voltar e vou reunir o povo. O senhor não leva o homem assim fácil não. E eu vou para a praça pública gritar contra o senhor". O capitão Ihe perguntou: “E o senhor faz isso?" “Faço. Não vá porque eu faço". O capitão foi embora sem levar Amaro Pedro. Depois disso, Bezerra foi diversas vezes interpelado pelos militares e obrigado a ir ao Recife prestar depoimentos. Como havia sido militar e possuía estatuto de excombatente16, conseguiu livrar-se das acusações. Suas idas à cidade eram 
acompanhadas de perto pelos moradores de Amaragi. Segundo o delegado sindical, eles temiam por sua sorte e se perguntavam, a cada vez, se ele voltaria. Bezerra encerra a parte do relato do acolhimento de Amaro Pedro, a um só tempo um elogio à sua própria bondade em relação a este último e à sua coragem para confrontar os militares.

Em seu relato, A maro Pedro refere-se à denúncia feita pelo patrão e ao episódio da busca policial. Não há referência nem aos companheiros nem às conversas que Bezerra Ihe atribui. A rigor, ele não diz quase nada a respeito de si mesmo. Bezerra é o eixo dessa parte do relato. São dele as palavras e frases que A maro Pedro menciona. É possível supor que ele tenha pedido uma casa: o patrão, afirma Amaro Pedro, disse-Ihe que podia vir, que havia uma casa para ele. A fórmula atribuída a Bezerra era aquela utilizada no momento da aceitação de um morador em um engenho. Poder-se-ia ser levado a crer que se tratava apenas de um pedido e da concessão da morada, se já não houvesse aparecido em seu relato referência à perseguição e se ele não houvesse acrescentado em seguida que o patrão Ihe dissera que não havia nada a temer; que a Polícia não Ihe faria mal porque em A maragi quem mandava era ele, Bezerra. Ademais, como na história contada por Bezerra, a Polícia foi procurá-lo no engenho, mas não o levou graças ao patrão.

Estes fatos são conhecidos em Rio Formoso. Eles foram certamente transmitidos aos mais jovens pelos velhos militantes e talvez pelo próprio Bezerra. Os dirigentes sindicais atuais fazem referência a esses episódios quando narram os eventos de 1964. Bezerra é citado como o patrão que não se comportou como os outros, que protegeu aqueles que eram perseguidos, que correu riscos. Amaro Pedro aparece então como o personagem de um caso que simboliza a conduta louvável do patrão. Há, todavia, uma outra história passada em A maragi que permaneceu oculta: a prisão de Zé Chico, delegado sindical. Seu irmão falou-me dela em 1995, mas não contou as circunstâncias. Quatro anos depois, em uma entrevista, o delegado sindical me disse que esteve na prisão por quinze dias, logo após o golpe. A Polícia foi procurá-lo por duas ocasiões no engenho. Conseguiu escapar na primeira vez, mas foi pego na segunda. De acordo com Zé Chico, Bezerra Ihe disse que apenas soube de sua prisão após o ocorrido, e que foi graças à sua intervenção junto a autoridades militares que ele não apanhou. Referiu-se em seguida aos rumores que, na época, circulavam em A maragi entre os moradores: logo que os policiais chegaram ao engenho, perguntaram quem era o delegado; Bezerra teria Ihes indicado um morador, que sabia onde morava o delegado sindical; os policiais levaram-no com ele e foi assim que puderam encontrar o sítio de 
Zé Chico. O antigo delegado não queria mal ao patrão por isso. A presentou diversos argumentos para justificar a conduta de Bezerra: ele não teria tido escolha, não podia negar a existência de um delegado sindical etc. A pós a prisão, Zé Chico retornou a A maragi, onde viveu e trabalhou até sua aposentadoria na década de 90. Como Amaro Pedro, morava em uma pequena casa na cidade de Rio Formoso e mantinha seu sítio no engenho, o qual era, na percepção dos moradores, um dos mais bonitos do engenho, coberto de numerosas e variadas árvores frutíferas que atestavam seu enorme investimento pessoal.

Seria necessário saber mais sobre esses dois episódios - a perseguição a A maro Pedro e a prisão de Zé Chico - para levar a análise mais longe, mas é possível desde já comparar a conduta do patrão nos dois casos e daí extrair implicações. Se Bezerra enviou ou não alguém para mostrar a casa de Zé Chico aos militares é uma questão secundária. M esmo na perturbação da ordem social que se segue ao golpe de Estado, é difícil acreditar que a Polícia tenha entrado no engenho sem que Bezerra estivesse a par disso. E se, por acaso, ele estivesse ausente, a Polícia não ousaria sair à captura de Zé Chico nas terras de Amaragi sem a autorização do patrão. É possível, portanto, imaginar que Bezerra foi informado. A questão que se impõe, portanto, é a de saber por que ele não se comportou do mesmo modo: por que não impediu a prisão de alguém que era morador seu havia anos, a quem ele já fornecera provas de sua confiança ao dar um sítio, com quem não possuía desavenças, ao passo que em relação a A maro Pedro, a quem mal conhecia, correu riscos e enfrentou os militares. Se o episódio de Zé Chico se passou após o de A maro Pedro, quando Bezerra já havia sido obrigado a ir ao Recife para se justificar perante as autoridades militares, ele certamente não estava em condições de enfrentar a Polícia. Nesse caso, ele não pôde proteger Zé Chico. Outra possibilidade: o episódio de Zé Chico ocorreu primeiro, logo após o golpe. Bezerra foi pego de surpresa. Não estava preparado para enfrentar a situação, sentiu-se impotente e nada pôde fazer. O caso de Amaro Pedro Ihe teria dado a oportunidade de redimir-se. Outras circunstâncias, entretanto, permitem compreender sua conduta em relação a A maro Pedro. Bezerra já lhe havia proposto tornar-se um de seus moradores. De acordo com seu relato, quando A maro Pedro foi procurá-lo, seu pedido era justamente por uma casa. Tudo se passou como se ele houvesse finalmente aceito o convite. Bezerra estava encurralado. Dizer não significaria não manter a sua palavra. Por outro lado, se, conforme conta o patrão, o homem Ihe pediu proteção, o constrangimento era redobrado. Para alguém como Bezerra, que tinha de si mesmo uma imagem de "homem 
bom" e a valorizava, recusar proteção a um trabalhador que se encontrava em perigo por causa de um patrão "perverso" era impensável. Tornaria o próprio Bezerra um "perverso". No ato de acolher Amaro Pedro estavam em jogo a sua honra e a preservação da sua auto-imagem, por meio da qual gostava de ser reconhecido e respeitado. Zé Chico não Ihe havia pedido sua proteção contra a Polícia. Não o fez porque não esperava que viessem procurá-lo? Teria sido muito orgulhoso para se dirigir ao patrão? É difícil saber. Os dois episódios, todavia, permitem mostrar que o poder de Bezerra tinha limites, que as coisas não se passavam como ele queria fazer crer a Amaro Pedro: "Em A maragi mando eu". Também ele foi atingido pela violência do Estado e não pôde cumprir sua função de protetor, exceto evitar que Zé Chico fosse torturado. $\mathrm{O}$ caso Amaro Pedro faz dele um herói, enquanto o episódio de Zé Chico expõe sua fraqueza; compreende-se melhor por que permaneceu oculto.

\section{Do processo ao perdão}

Alguns meses após o golpe, o sindicato de trabalhadores rurais de Rio Formoso foi reaberto, e em 1965 houve a el eição da nova diretoria. Trabal hadores que jamais haviam tido funções sindicais chegaram então à direção e passaram a investir progressivamente na implantação de serviços jurídi$\cos$ no interior dos sindicatos ${ }^{17}$. O direito trabal hista permanecia em vigor e a J ustiça do Trabalho em pleno funcionamento. Os militares e seus aliados civis não se opunham ao recurso à J ustiça como modo de regulação de conflitos e, pode-se dizer, até o estimularam. Ainda no ano de 1965, o Instituto Brasileiro de Reforma Agrária (IBRA), então um órgão vinculado à Presidência da República, firmou um acordo com a Federação dos Trabalhadores na Agricultura de Pernambuco (Fetape), que congregava os sindicatos dos trabalhadores rurais do estado, para contratar advogados trabalhistas. Foi graças a este acordo que o Sindicato de Rio Formoso pôde ter seu advogado e começar a ajuizar ações na J ustiça do Trabal ho.

Amaro Pedro conta que, uma vez instalado com a família em Amaragi, ficou trabalhando no engenho, nos canaviais do patrão e em seu sítio. Bezerra Ihe dera uma área, no meio da mata, para formar o sítio. Só havia um pé de coqueiro e tudo estava por fazer. No relato, Amaro Pedro diz que tudo corria bem: ele não perturbava o patrão, nem este o incomodava. Um dia, no ano de 1965, sem saber o que Ihe passou pela cabeça, conta que botou questão18 contra Bezerra. Sobre o restante de sua versão, seu arrependimento, já se falou anteriormente. $\mathrm{Na}$ entrevista, conti- 
nuei a lhe fazer perguntas para saber mais sobre o episódio. Bezerra, precisou ele, não estava em dia com as obrigações trabalhistas. Foi então ao sindicato buscar uma orientação, sendo o único de Amaragi a fazê-lo. Os dirigentes sindicais aconsel haram-no a reclamar na J ustiça e o encaminharam para o advogado. No contexto de implantação dos serviços jurídicos, levar os trabalhadores à J ustiça era percebido como a função por excelência dos sindicalistas, que não podiam mais organizar greves ou manifestações. Compreende-se, portanto, o consel ho que deram. No engenho, Bezerra dava a seus moradores outro consel ho. Dizia que não precisavam procurar o Sindicato, que o Sindicato era perda de tempo e, em uma alusão à perseguição pós-golpe, que todos já haviam visto no que dava meter-se em atividades sindicais.

Ir ao Sindicato para se queixar do patrão não era ainda uma prática corrente em 1965. A violência da repressão havia contribuído para que se instalasse o medo no município19, e todo um trabalho pedagógico junto aos assalariados agrícolas teve que ser feito para que eles voltassem ao Sindicato. Amaro Pedro não informa o momento preciso em que restabeleceu os laços com os companheiros. É provável que tenha sido um dos primeiros a fazê-lo e que, tendo anteriormente participado das lutas sindicais, se sentisse obrigado em relação àqueles que buscavam revitalizar o Sindicato na nova conjuntura. Entendendo que a luta sindical se fazia doravante pela via jurídica, Amaro Pedro fez o que os dirigentes sindicais dele esperavam: aceitou botar questão contra o patrão; reafirmou sua intenção quando disse a Bezerra que era ele mesmo que o estava processando, como relata o dono de A maragi; e levou o processo até o fim, comparecendo à audiência na J unta.

Quando a questão já estava resolvida do ponto de vista sindical, Amaro Pedro perguntou-se então: “M as o que foi que eu fiz a Seu Zé Bezerra?" Procurou o patrão e Ihe pediu perdão. Não poderia proceder de outro modo se desejava permanecer em Amaragi. Dado o caráter personalizado das relações no engenho, A maro Pedro ali não poderia continuar morando se o patrão não se dispunha mais sequer a cumprimentálo. Em seu relato, ele reproduz apenas as palavras do patrão: nada se sabe do que disse a Bezerra e não há nenhuma referência às lágrimas ou à restituição do dinheiro ganho na J unta. Foi, certamente, um ritual de humilhação, ao qual o pudor Ihe impedia de retornar, mesmo passados trinta anos do episódio.

O processo e o pedido de perdão parece ter permanecido um assunto concernente apenas a Bezerra e A maro Pedro. Nos períodos em que estive em Rio Formoso (entre 1994 e 1999), ninguém jamais falou sobre 
esse assunto, ao passo que o episódio do acol himento era um fato notório. O processo era fundamentalmente um problema para o patrão. Foi ele que o mencionou por ocasião de nosso encontro. Tomado pela lógica do dom que se quer gratuito, mas que é na verdade interessado, como assinalava M arcel Mauss, Bezerra nunca pôde compreender que Amaro Pedro entrasse na J ustiça contra ele. A colher um homem perseguido pela Polícia era uma manifestação quase sublime de sua generosidade. A expectativa era a de que o contradom se fizesse sob a forma de uma lealdade inabalável. N essas circunstâncias, o processo não podia ser percebido senão como uma ingratidão. Como Bezerra via naquele que havia acolhido não mais que um "pobre homem", não lhe ocorria que "esse homem" pudesse ter lealdades outras que não aquela com quem Ihe havia salvado a vida. Ora, quando Amaro Pedro foi procurá-lo, Bezerra interpretou seu gesto como uma confissão de que entrar na J ustiça fora um erro. Era uma vitória para ele. Por meio do perdão confirmou sua bondade, e a ordem social no engenho fundada na autoridade pessoal de seu dono foi plenamente restabelecida. De sua parte, A maro Pedro somente se referiu ao processo porque sabia que eu estava interessada nessa história. Seu relato foi feito na varanda da casa de Roberto, filho do patrão, que havia providenciado a vinda de Amaro Pedro para que ele mesmo me narrasse os acontecimentos. Sem que eu Ihe inquirisse, referiu-se à questão com Bezerra e qualificou o episódio como uma "fraqueza de juízo" de sua parte. Dadas as circunstâncias, não surpreende que ele tenha apresentado desse modo o episódio: era a versão apropriada ao local da conversação. M as esta, certamente, correspondia à maneira pela qual A maro Pedro via sua ida à J ustiça contra o patrão, uma vez que também ele reagia a partir da lógica do dom: a "fraqueza de juízo" encobria o sentimento de haver faltado com a obrigação de retribuir o dom recebido, de haver se comportado como um ingrato20.

\section{A proteção até o fim}

A pós a promulgação do Estatuto do Trabalhador Rural, os patrões da zona canavieira de Pernambuco foram forçados a se submeter a obrigações que lhes eram até então desconhecidas, como estabelecer contratos de trabalho formal mediante assinatura das carteiras de trabalho, e pagar o salário mínimo, o repouso remunerado, o 130 salário, as indenizações por demissão etc. Como as instituições estatais, à exceção dos Tribunais do Trabalho, pouco controlavam os patrões no que diz respeito ao cumpri- 
mento da legislação trabal hista, a pressão sobre a classe patronal foi exercida primordialmente pelos dirigentes sindicais, que, desde a segunda metade dos anos 60, passaram a investir sistematicamente na regulação jurídica dos conflitos. Com o passar do tempo, ajuizar grande número de reclamações contra os patrões tornou-se sinal de excelência no campo sindical. Aqueles que pretendiam ascender na hierarquia de prestígio redobraram seus investimentos: estimulavam os trabalhadores a fazer reclamações, colocavam à sua disposição todo um conjunto de dispositivos (advogados, principalmente) para entrar com a questão nas J untas e seguiam de perto o andamento do processo.

Esta dinâmica contribuiu para a introdução do direito como regulador das relações sociais nos engenhos. As estatísticas das J untas mostram que os processos raramente eram arquivados e que o mais freqüente era a vitória dos trabalhadores na J ustiça. Muitos patrões se ajustaram ao direito para evitar a luta judicial; outros passaram a seguir as regras após um primeiro processo, negociando acordos amigáveis que levavam em conta o direito do trabalho. Por outro lado, como, conseqüentemente, aumentou o custo da força de trabalho, os patrões trataram de buscar outras soluções para ter trabalhadores disponíveis. Recorreram a empreiteiros e restringiram a recepção em suas terras de candidatos a um contrato formal, a fim de reduzirem os encargos sociais e os riscos de serem levados à J ustiça, que acarretava prejuízos monetários e era percebido como uma desonra.

Nas décadas de 60 e, sobretudo, 70, houve uma expansão importante da agricultura da cana em Pernambuco, graças a uma política favorável do governo federal em relação à agroindústria açucareira, especialmente no que tangia aos créditos e à exportação de açúcar. Quando dessa expansão, uma parte significativa da mão-de-obra empregada nas plantações começou a ser constituída por trabal hadores recrutados sem contrato de trabalho, dos quais a mai oria vivia nas pequenas cidades da zona canavieira, uma vez que a morada se havia fechado para eles. Estes trabal hadores eram chamados e se auto-reconheciam como clandestinos, em oposição aos fichados. A relação com os direitos desempenhava, portanto, a função de princípio classificatório, o que demonstra o quanto já haviam se tornado uma referência para os trabalhadores da região.

Em Rio Formoso, os dirigentes sindicais recorreram ao auxílio de um advogado de esquerda, incumbido de explorar as possibilidades das normas jurídicas para proteger da demissão os fichados que ainda viviam nos engenhos. Esta estratégia jurídica teve o efeito de assegurar a permanência de alguns milhares de moradores nas plantações, mas não che- 
gou a reverter a tendência dos patrões de fecharem as portas dos engenhos aos recém-chegados ou de se recusarem a estabelecer com eles contratos de trabalho.

Em Amaragi, Bezerra não demitia ninguém e continuava a receber trabal hadores em suas terras, assinando as carteiras de trabal ho de alguns e deixando outros morarem e trabalharem no engenho como clandestinos. Tal qual no período anterior aos direitos, o patrão de Amaragi acolhia os novos como moradores; permitia a todos, fichados e clandestinos, que botassem roçados; distribuía sítios e se comportava como um protetor, agindo conforme sua imagem de "homem bom". Esta conduta era inusitada no município. O irmão de Bezerra, por exemplo, à época arrendatário de dois engenhos da Usina Central Barreiros (Serra d'Água e Minguito), destruía sistematicamente as casas dos trabal hadores que deixavam o engenho, não acolhia novos moradores e não distribuía sítios.

Em 1979, iniciado o processo de redemocratização no Brasil, houve uma retomada das greves na zona canavieira. Os Sindicatos de São Lourenço da M ata e de Paudalho, municípios situados na região metropolitana do Recife, tomaram a iniciativa, com o apoio da Fetape e da Confederação Nacional dos Trabalhadores na Agricultura (Contag), de propor aos sindicatos patronais um contrato coletivo de trabalho. Como os patrões não responderam à solicitação no prazo de cinco dias regulamentados por lei, os dirigentes sindicais convocaram uma greve. Vinte mil trabaIhadores cruzaram os braços. Outros 22 sindicatos, incluindo o de Rio Formoso, aderiram à reivindicação do contrato coletivo e anunciaram sua disposição de também aderir à greve. Os representantes patronais aceitaram então negociar com os dirigentes sindicais e terminaram por assinar um acordo, do qual se beneficiariam os trabalhadores de toda a zona canavieira. Este primeiro acordo previa, entre outras coisas, um aumento de $52 \%$ do salário, a fixação de uma tabela de tarefas (estabelecendo equivalência entre tamanho das tarefas e preços) e a extensão de alguns direitos dos trabal hadores urbanos, como o pagamento de horas extras etc. Nos anos que se seguiram, os contratos, cuja duração era de doze meses, foram renovados no quadro dos acordos ou graças à intermediação do Tribunal do Trabalho, muitas vezes com a eclosão de greves nas quais chegavam a estar envolvidos até duzentos mil trabalhadores ${ }^{21}$.

Depois do primeiro contrato, os sindicatos chegaram também a incluir nos seguintes obrigações que remetiam à tradição da morada, como a concessão do sítio e as despesas de manutenção das casas dos trabaIhadores nas plantações; alguns anos mais tarde, incluíram uma espécie de proteção aos doentes, como o transporte para o hospital. Esta inclusão 
somente se explica porque os trabalhadores, a rigor, continuavam a orientar-se segundo as normas que prevaleciam nas plantações antes da extensão dos direitos sociais. Como pude observar, desde as minhas primeiras idas a campo, no início dos anos 70 , os trabal hadores queixavam-se de que os patrões não Ihes davam mais sítios, que não Ihes ajudavam quando estavam doentes, que não mais consertavam suas casas. Acreditavam que tal mudança de comportamento tivesse sido causada pela chegada dos direitos e a descreviam valendo-se da linguagem dos sentimentos: os patrões tinham sido tomados por uma espécie de "ódio" em relação a seus moradores. Com os contratos coletivos oriundos das greves, algumas das obrigações da morada foram postas sob a égide da coerção jurídica: tornaram-se direitos.

Quando houve a primeira greve de Rio Formoso, em 1980, a paralisação foi massiva. Os dirigentes sindicais, entretanto, não chegaram a parar o trabalho em Amaragi. Bezerra e seu filho reagiram à entrada dos líderes no engenho. Nos anos seguintes, quando ocorreram outras greves, deram férias coletivas aos trabalhadores. Deste modo, asseguravam a interrupção do trabalho e agradavam aos dirigentes sindicais, com quem Bezerra e Roberto mantinham boas relações, e, ao mesmo tempo, faziam ver a sindicalistas e trabal hadores quem detinha o poder em Amaragi. Com as greves, os processos multiplicaram-se na zona canavieira: os dirigentes estimulavam os trabal hadores a recorrerem à J ustiça para garantirem o respeito aos novos direitos incluídos nos contratos coletivos. Rio Formoso ocupava o terceiro lugar em número de processos na zona canavieira22. Nenhum, no entanto, foi registrado em A maragi. Os moradores, todos sindicalizados, não iam à J ustiça contra Bezerra: o reconhecimento de que o patrão era um "homem bom" os impedia moralmente. De sua parte, Amaro Pedro permaneceu fiel a Bezerra, mas não enfraqueceu por isso seus laços com o Sindicato. Continuava a freqüentar as reuniões sindicais e desenvolvia em Amaragi todo um trabalho pedagógico junto aos novatos: ensinava-Ihes o que era o sindicato, seu papel na defesa dos "direitos" e os estimulava a participar das atividades sindicais ${ }^{23}$.

Com a vigência dos contratos coletivos, os sindicatos colocaram em marcha uma estratégia para assegurar o registro de todos os trabalhadores e acabar com o trabal ho sem a garantia dos direitos. Os patrões viram-se, assim, cada vez mais, forçados a firmar contratos de trabal ho com os clandestinos. A lém disso, tiveram que pagar mais caro para dispor de mão-de-obra nas plantações, por conta do aumento dos salários e do restabelecimento da tabela de tarefas. Nesse contexto, generalizou-se a uti- 
lização de carregadeiras mecânicas da cana cortada para fazer frente à necessidade de reduzir o número de braços durante a moagem.

Em Amaragi, onde desde 1983 Bezerra já havia transferido a gestão da plantação a seu filho, diversos clandestinos tornaram-se fichados e novas máquinas foram adquiridas para enfrentar a conjuntura. Mais ou menos nessa época, muitos trabal hadores começaram a deixar o engenho para ir trabal har em São Paulo. Em algumas ocasiões, partiam famílias inteiras; em outras, apenas jovens celibatários cujos pais e outros membros da família permaneciam em Amaragi, espécie de "porto seguro" para o caso de as coisas não saírem tão bem. Quatro dos quatorze filhos de A maro Pedro, bem como o marido de sua filha mais velha (Quitéria), foram alguns dos que partiram. A filha, que morava em um engenho vizinho, voltou com seus filhos para a casa paterna em Amaragi e começou a trabalhar no engenho. A pós dois anos, o marido retornou de São Paulo e foi trabal har em outro engenho. Quitéria acompanhou-o, mas manteve seu contrato de trabal ho em Amaragi e ali deixou um de seus filhos, J osé Augusto, apelidado Cabeludo, morando com o avô Amaro Pedro.

No início da década de 90, o governo federal mudou a política em relação à agricultura canavieira: suspendeu os subsídios, liberou aumentos nas taxas de juros e privatizou as exportações, até então feitas com a mediação do Instituto do Açúcar e do Álcool, que garantia preço aos produtores. $\mathrm{Na}$ zona canavieira de Pernambuco, houve os patrões que não conseguiram fazer face à nova conjuntura e faliram; outros tantos trataram de se reestruturar e para tanto demitiram em massa. Das 38 usinas de Pernambuco, quatorze já não funcionavam em 1997; a produtividade atingida nos anos 80 de quase 26 milhões de toneladas de cana transformadas em açúcar chegava a apenas 15 milhões na col heita de 1997/98. Ao final dos anos 90, das quatro usinas que se encontravam em Rio Formoso e arredores, apenas a Trapiche conseguiu se reestruturar; Cucaú sobreviveu de modo precário; Santo André não explorou mais seus engenhos; e Central Barreiros, que fora a usina mais poderosa de Pernambuco nos anos 70, fechou suas portas. De início, os sindicatos fizeram tudo para proteger os trabalhadores da demissão. Todavia, na medida em que o emprego estável rareava, o poder de negociação dos sindicatos se enfraquecia e os contratos de trabal ho tornavam-se mais precários. Os processos judiciais multiplicaram-se, mas em uma outra lógica: tratava-se, a partir de então, de assegurar o pagamento das indenizações aos demitidos, e não mais cobrar direitos para garantir o emprego.

Nesta nova conjuntura, o M ovimento dos Trabalhadores Rurais Sem Terra (MST), organização criada nos anos 80 no sul do Brasil para reivin- 
dicar a desapropriação de terras por meio de ocupação de fazendas, começou a se instalar em Pernambuco. Em 1992, o MST organizou a primeira ocupação de terra de envergadura na zona canavieira. Mais de mil pessoas, a maioria trabalhadores dos engenhos, entraram nas terras do engenho Camaçari, em Rio Formoso. Os dirigentes sindicais deste município deram seu apoio e participaram da ação. Nos anos seguintes, outras ocupações ocorreram em Rio Formoso e no antigo distrito de Tamandaré, tornado município em 1996. De início, foram produto da colaboração do MST com o sindicato, e a partir de 1996, promovidas em separado pelas duas organizações 24 .

Em Amaragi, desde o fim dos anos 80, o filho de Bezerra, antevendo as dificuldades da agroindústria canavieira, associou-se a um empresário alemão e se preparou para a conversão ao turismo. A proveitando a localização privilegiada de Amaragi, entre a estrada e a parte tida como a mais bonita da costa pernambucana, fez da casa-grande um hotel-fazenda e começou a receber um fluxo importante de turistas. Bezerra não estava de acordo, porém, já vel ho e doente, nada pôde fazer. Em meados dos 90, as dificuldades do setor açucareiro fizeram-se sentir em A maragi: endividado junto ao Banco do Brasil e em conflito com a usina, que lhe havia confiscado parte da produção, Roberto não tinha mais condições de honrar os salários ${ }^{25}$. De início, os trabal hadores contornaram a situação com os produtos de seus sítios e da pesca; alguns foram trabalhar como clandestinos para outros patrões. A pós algumas semanas, a fome instalou-se no engenho. Roberto mandou matar três bois para distribuir carne às famílias; em seguida, obteve crédito em um mercado da cidade para que nele os trabal hadores pudessem se abastecer. A suspensão do pagamento era uma situação inusitada para os trabalhadores rurais. A maioria deles morava em Amaragi havia muitos anos e jamais tinham vivenciado algo semelhante. Parecia-Ihes que Roberto era o principal responsável pelo que se passava: ele teria privilegiado o hotel-fazenda e negligenciado o cultivo da cana. O engenho, que produzira trinta mil toneladas de cana, produzia agora apenas seis mil. Os trabal hadores esperavam, todavia, que Roberto encontrasse uma solução, que desempenhasse a função de protetor como seu pai. A lém disso, temiam que Roberto partisse, como outros patrões de Rio Formoso estavam fazendo, ou que a usina tomasse o engenho.

Quando a crise eclodiu em A maragi, A maro Pedro já não morava mais lá. Alguns anos antes tinha sido vítima de um derrame, ao qual sobreviveu graças a Bezerra, que o levou para o hospital - salvando, assim, sua vida pela segunda vez, de acordo com sua representação dos fa- 
tos. Em seguida, sentindo-se abatido, aposentou-se e foi se instalar em uma pequena casa na cidade para estar próximo a um socorro médico. Quitéria, a única de seus filhos a possuir um contrato de trabalho em Amaragi, continuou a trabalhar no engenho e a tomar conta do sítio do pai. O neto que Amaro Pedro criara, Cabeludo, jamais fora um fichado, nem em Amaragi, nem em parte al guma. Nascido em 1970, chegou à idade de trabalhar (em torno de 14 anos) em um momento em que os patrões preferiam recrutar jovens com contratos temporários, apenas para o período de colheita da cana. N esta condição, circulou por diversos engenhos e terminou por se instalar na cidade com seu padrinho, que havia sido dirigente sindical. $\mathrm{Na}$ cidade, começou a fazer "bicos". Mantinha-se em contato com os dirigentes sindicais que já conhecia, uma vez que seu avô o levava freqüentemente às reuniões. Em 1992, quando dos eventos no engenho Camaçari, estava desempregado. Um de seus amigos do Sindicato convidou-o para participar da ocupação. Cabeludo, a princípio reticente, aceitou o convite. Ocupar um engenho era algo fora de seus horizontes, bem como para os outros trabalhadores da região. Quando da saída de Camaçari, em conseqüência de uma grande operação militar, Cabeludo integrou-se ao contingente de cerca de oitocentas pessoas que seguiram os líderes do MST e do Sindicato e instalaram-se em outro local para preparar uma nova ocupação. Em menos de um ano, foram três ocupações ${ }^{26}$. O grupo foi aos poucos se reduzindo, mas Cabeludo foi sempre parte dele. Em 1997, quando o encontrei pela primeira vez, já era um militante do MST, responsável por uma microzona compreendendo alguns municípios do litoral (Rio Formoso inclusive), e havia tido participação ativa em diversas ocupações de terra.

Em Amaragi, Roberto não conseguiu superar a crise e terminou por investir cada vez mais no turismo. Os trabalhadores permaneceram em seus sítios e continuaram a procurar trabal ho fora do engenho. Se o nível de desemprego era elevado na zona canavieira, os trabalhadores de Amaragi eram privilegiados em relação aos outros: não tinham sido postos para fora e podiam continuar a cultivar os roçados. Como no passado da morada, o patrão protegia-os da crise e os deixava trabalhar a terra para eles mesmos. O governo federal já havia começado a desapropriar engenhos na área para redistribuir as terras, sendo que essas desapropriações ocorreram sempre ali onde houvera ocupações organizadas pelo MST, pelos sindicatos e outros movimentos ${ }^{27}$. Em Rio Formoso, a primeira desapropriação ocorreu em 1994 (engenho Cipó ocupado pelo M ST e Sindicato) e a segunda, em 1996 (engenho São J oão ocupado pelo Sindicato). Roberto, certamente, viu na desapropriação uma solução para a crise 
em A maragi: com o engenho desapropriado, ele se livraria das obrigações trabalhistas com os moradores e poderia se beneficiar das indenizações em dinheiro referentes às benfeitorias feitas no engenho por seu pai desde 1952. A indenização da terra, paga em títulos da dívida agrária, caberia à Usina Central Barreiros, proprietária do engenho. Há indícios de que houve um entendimento entre Roberto e os dirigentes sindicais e que estes então solicitaram ao Instituto Nacional de Colonização e Reforma Agrária (INCRA) a desapropriação do engenho, alegando que as terras eram improdutivas ${ }^{28}$. Em 1998, ocorreu a desapropriação. Ao contrário de outros engenhos da região, que ao serem desapropriados já estavam quase vazios, como, por exemplo, os dois pertencentes ao irmão de Bezerra ${ }^{29}$, em A maragi havia uma população de quase quatrocentas pessoas. Eram famílias que lá estavam há décadas, algumas desde a chegada de Bezerra nos anos 50, e que aí permaneceram graças, sobretudo, à proteção que lhes era garantida pelo dono do engenho. É verdade que, como os outros patrões, nem Bezerra nem seu filho obedeciam na letra da lei a todas as obrigações trabal histas e que tinham acumulado inúmeras dívidas que os moradores não cobravam em respeito às obrigações impostas pela gratidão. M as se em outros engenhos em situação semeIhante o momento da desapropriação foi também um momento de acerto de contas na J ustiça dos moradores em relação aos patrões, tal não ocorreu em Amaragi. Querendo estar à altura do pai e de sua reputação de homem "bom", Roberto fez um acordo inédito com o Sindicato e o INCRA: propôs que da indenização que lhe era devida pelo Instituto fosse deduzida a quantia referente ao passivo trabalhista para fins de quitação das obrigações com os moradores. Tudo se passou, portanto, como se até o fim o que estivesse em jogo fosse preservar a honra do patrão e evitar a desonra de ser levado à J ustiça.

\section{Tudo o que o direito deve à honra}

Ser reconhecido e respeitado como "homem bom" conferia para Bezerra sentido à sua vida e ele se comportava com a preocupação de produzir e reproduzir esta imagem de si mesmo30. Esta preocupação o levou a agir como os patrões mais veneráveis do passado da morada e a respeitar as normas da tradição, mesmo quando os patrões começaram a negligenciar suas obrigações tradicionais e a não mais valorizar a generosidade. Dentro e fora de Amaragi, entre aqueles que estiveram ou não submetidos ao seu mando, logrou ser visto como um "homem bom", como um 
"homem de ouro". A veneração que muitos trabal hadores tinham e ainda têm por ele pode ser interpretada como um culto à tradição que fundava a legitimidade da morada e que Bezerra se empenhou em respeitar.

A mesma vontade de ser reconhecido como homem "bom" parece estar também na origem de sua relação com o direito. Não sendo um partidário da legislação trabalhista, Bezerra, contudo, procurou, na medida do possível, cumprir desde o início as novas regras. Diante do risco de ver sua autoridade questionada pela reivindicação de respeito aos direitos, como ocorria com outros patrões, tratou de assegurar a seus moradores o pagamento do salário mínimo, do 13o salário e a assinatura da carteira de trabalho. Graças a tal iniciativa, pôde impedir que o movimento de protesto chegasse a Amaragi e garantiu a continuidade inabalável de seu poder sobre aqueles que estavam submetidos a ele por relações de morada. Em suas falas, Bezerra sempre apresentava o respeito aos direitos como prova de sua bondade, jamais como submissão a uma imposição jurídica vinda de fora. E era também esta a percepção que tinham os homens que habitavam seu engenho: cumpria os direitos porque era um homem "bom". Sobre os moradores de A maragi, sempre exerceu uma dominação personalizada: sua autoridade era pessoal e ele se fazia obedecer graças ao respeito à tradição, na qual ele soube incluir os "direitos".

Compreende-se melhor o episódio de Amaro Pedro levando-se em conta o desejo de Bezerra de ser reconhecido como homem bom no contexto das lutas sociais e de esvaziamento da morada. O mundo havia mudado, mas Bezerra continuava a se comportar como "antes do direito" e dos protestos dos moradores. A colheu um "comunista" para honrar sua palavra, tratou-o como um de seus moradores porque não podia agir de outro modo e o perdoou porque A maro Pedro se humilhou perante ele. $O$ episódio é uma demonstração extrema deste que foi o modo pelo qual Bezerra geriu as relações com seus moradores, do "anacrônico triunfo da honra", para retomar os termos da análise de Duby (1984) a propósito de Guilherme Marechal, a quem podemos comparar com a personagem de Bezerra.

A maro Pedro era menos eloqüente que Bezerra e que a maioria dos trabalhadores que conheci: um homem de poucas palavras, monossilábico e discreto. Gozava de prestígio entre os sindicalistas e seu nome era freqüentemente citado na lista dos que participaram das lutas e sofreram perseguição militar. Todavia, seu papel nas lutas heróicas do período de chegada dos direitos jamais foi objeto de um discurso de autoconsagração. Destas suas particularidades decorre que se saiba menos sobre ele do que sobre Bezerra e que seja mais difícil identificar claramente seus 
próprios desejos, o sentido que suas condutas tiveram para ele na seqüência dos eventos que vão do período em que ele se torna delegado sindical até a fuga para Amaragi, do processo ao perdão. Amaro Pedro tinha certamente qualidades reconhecidas por seus pares como apropriadas para enfrentar os patrões. Tornar-se delegado sindical era, à época, como nos dias atuais, uma posição prestigiosa, e A maro se orgulhava disto a ponto de recusar o convite de Bezerra, como se viu. Para manter a posição, um homem devia dar provas de sua capacidade. Ao que tudo indica, Amaro Pedro desempenhou bem sua função, posto que conseguiu construir um nome e uma reputação. Quando o mundo desabou sobre sua cabeça, por causa da violência da repressão, aqueles que nele reconheciam um homem honrado nada puderam fazer, já que foram igualmente atingidos pela violência do Estado. Foi nesse contexto que A maro pediu proteção a Bezerra, como faziam os moradores com os patrões quando se sentiam em perigo, mas não pelas mesmas razões. Ele, que se empenhava para que as relações no interior das plantações fossem reguladas de outro modo, não teve outra escolha senão a de se comportar segundo a tradição. Sua vida estava em risco. Botar questão contra o patrão um ano após ter sido por ele protegido constitui um fato extraordinário apenas quando se permanece, como Bezerra, prisioneiro da lógica do dom e do contradom. Seu ato também pode ser interpretado como produto de sua lealdade em relação aos companheiros do Sindicato e da vontade de A maro Pedro de ver o direito respeitado.

Não cabe ao antropólogo pôr em dúvida a representação que os indivíduos fazem dos eventos. Pode, no entanto, formular hipóteses diferentes das interpretações dos nativos. É provável que A maro Pedro se questionasse, desde o início, a respeito do que estava fazendo a Bezerra e que se sentisse atormentado todo o tempo que decorreu entre a reclamação e a audiência. $M$ as ele também tinha uma imagem de si mesmo a preservar perante os dirigentes sindicais. Durante os 24 anos que permaneceu em Amaragi, Amaro Pedro não exerceu funções sindicais; era, no entanto, freqüentador assíduo das reuniões do Sindicato e respeitado pelos dirigentes sindicais. Durante esse período, permaneceu leal a Bezerra e jamais pôs novamente em questão sua autoridade. $O$ fato de seu neto Cabeludo desempenhar uma função nas mobilizações pela desapropriação de terras, como Amaro Pedro havia desempenhado nas mobilizações pela implantação do direito, não pode, no entanto, ser tomada apenas como o resultado da participação do avô na social ização do neto. Reuniramse outras condições sociais, que não serão examinadas aqui, para que isso acontecesse. M as não se pode evitar supor que A maro Pedro tenha 
contribuído para que seu neto tivesse adquirido um habitus que o dispôs a enfrentar os patrões.

\section{Conclusão}

A especialização crescente no interior de disciplinas como a antropologia e a sociologia, produzida antes por lógicas particulares ao funcionamento dos establishments científicos do que pelas necessidades do saber, tem efeitos perversos sobre o desenvolvimento das ciências sociais. Presos na armadilha de uma divisão do trabalho intelectual, que é somente histórica, os praticantes dessas disciplinas terminam por crer na autonomia do domínio de estudo de sua escolha - a religião, a política, a cosmologia, para mencionar apenas alguns - em relação a outros domínios da vida social, os quais não levam em conta ao produzirem interpretações. Entre aqueles que no campo da antropologia e da sociologia se especializam no estudo do direito, os efeitos perversos parecem ser dobrados, uma vez que ali a autonomização conduz freqüentemente a tomar o objeto a partir do ponto de vista dos experts (juízes e advogados) e dos indivíduos e grupos interessados no direito. É isto que se observa, por exemplo, nos estudos que se limitam quer às normas ou às instituições jurídicas, quer ao reclamante, e não se preocupam em relacionar os fatos ligados ao direito com outros fatos sociais. Assim, quando se trata de explicar, por exemplo, a ida à J ustiça para a regulação de conflitos, o ol har é dirigido seja sobre os reclamantes - sobre sua tomada de consciência das injustiças, sobre suas possibilidades de acesso às instituições jurídicas -, seja sobre o conteúdo das normas e a função dos experts (advogados e magistrados). Tudo se passa, então, como se não fosse necessário ir além do direito, como se fosse possível compreender esta prática sem fazer a sociogênese dos conflitos, sem se interrogar sobre as propriedades sociais dos indivíduos envolvidos e a história de suas relações, sem, enfim, reinscrever os fatos relevantes do direito em quadros sociais mais amplos. E quando se volta aos escritos de alguns "fundadores" de disciplinas como a antropologia e a sociologia, vê-se que foi justamente a especialização que contribuiu para essa situação. A ênfase na relação dos fatos do direito com outros fatos sociais, tão negligenciada nos dias atuais, foi formulada como recurso de método e praticada, no período que precedeu a especialização perversa, por M arcel M auss (1991), em seu estudo sobre as trocas e os contratos nas sociedades arcaicas, e por Bronislaw Malinowski (1970), em suas análises sobre os costumes e as coerções à circulação de 
dons nas ilhas Trobriands. E na obra daquele que foi jurista antes de se tornar sociólogo, Max Weber, encontram-se construções teóricas que insistem sobre o fato de que as condutas não podem ser compreendidas se apenas se leva em conta o direito, bem como alertas contra a contaminação do ponto de vista sociológico pela dogmática jurídica.

A partir de um caso preciso, tentei mostrar que é possível chegar a uma compreensão mais adequada dos fatos ligados ao direito uma vez que, rompendo com o ponto de vista que os autonomiza, se amplia o quadro de análise. A introdução do direito como regulador das relações sociais nas plantações canavieiras de Pernambuco foi inicialmente o efeito de uma mudança de ordem jurídica. Mas, ao contrário daquilo que diriam os especialistas, isso não se pode explicar somente pela existência de novas normas jurídicas, nem pelo funcionamento das instituições jurídicas. Nas regiões canavieiras vizinhas, na Paraíba e em Alagoas ${ }^{31}$, à extensão dos direitos sociais não se seguiram os mesmos efeitos. Para que os direitos sociais se tornassem efetivos, foi necessária toda uma mobilização para que se os respeitasse. N ela engajaram-se os dirigentes sindicais e líderes como A maro Pedro, o qual contribuiu para que o direito entrasse no engenho Porto Alegre. Mas a própria mobilização se torna compreensível porque havia ocorrido antes uma ruptura com a tradição: esta ruptura contribuiu para que as pessoas se mobilizassem em torno dos “ direitos", percebidos como compensação à perda da proteção da tradição.

Da chegada dos direitos até a década de 90 , a introdução do direito foi produto das lutas sindicais, inicialmente através das grandes mobilizações (1963-64), depois por via da regulação jurídica do conflito e tudo aquilo que a supunha, como ensinar aos trabalhadores seus direitos e a implantação de uma infra-estrutura para recorrer à J ustiça (décadas de 60 e 70), e, por fim, por meio das mobilizações coletivas em torno dos contratos de trabalho, que criaram novas obrigações patronais - novos "direitos" - e juridicizaram as obrigações da tradição. Durante todo esse período, o respeito aos direitos, progressivamente, passou a ser percebido pelos trabalhadores rurais como uma proteção, a partir do modelo daquela que Ihes era garantida pelos patrões no contexto da morada. Quando a crise eclodiu na zona canavieira, muitos trabalhadores sentiram que estavam à beira de perder tudo: não havia mais nenhuma proteção, nem da tradição nem do direito. Esta representação contribuiu para que se dispusessem a ocupar os engenhos e a começar a inventar um novo direito: o direito à terra.

O caso de Amaragi permite, por fim, complexificar mais o quadro e perceber que houve outras condições sociais que contribuíram para que 
o direito se tornasse efetivo: ali, um patrão tomado pelo desejo de ser reconhecido como "bom" respeitou os direitos para preservar sua reputação e sua autoridade pessoal - por razões, portanto, que não derivam do direito. Graças a esse desejo, deu abrigo a Amaro Pedro e o protegeu, assim como a Zé Chico. Estes, por sua vez, contribuíram para a efetividade do direito, dedicando-se com esmero à conversão dos companheiros aos direitos e aos sindicatos. No fim, as coisas se passaram de modo diferente em A maragi. A proteção tradicional foi assegurada até o fim; o engenho não foi ocupado da maneira que outros o foram; o patrão assumiu suas dívidas com os trabal hadores. Porém, como o mundo não é tão simples conforme tendem a crer aqueles que o observam a partir de modelos dicotômicos, Amaragi, o engenho da dominação pessoal, foi também o berço de um novo líder - o neto de A maro Pedro - , que enveredou pelo caminho da militância e, por meio dela, das mobilizações pela desapropriação dos engenhos, com tudo que ela tem implicado em termos de redução dos diferenciais de poder do mundo das grandes plantações da mata pernambucana.

Recebido em 15 de novembro de 2003

A provado em 4 de março de 2004

Lygia Sigaud é professora do Programa de Pós-Graduação em Antropologia Social do Museu Nacional/UFRJ . E-mail: \sigaud@alternex.com.br> 


\section{Notas}

1 Engenho é o termo mais corrente para designar as unidades de produção de cana-de-açúcar. Outros termos utilizados são fazenda e propriedade.

2 Sobre o papel desempenhado por padres da Igreja Católica nesse período, ver Palmeira (1977a).

$3 \mathrm{Na}$ ocasião, eu realizava uma pesquisa sobre os usos sociais do direito naquela região da mata pernambucana e Amaragi era um dos engenhos estudados.

${ }^{4} \mathrm{~A}$ análise do caso J osé Bezerra-A maro Pedro foi elaborada a partir de um relato dos dois a respeito dos acontecimentos, de entrevistas feitas com delegados sindicais, sindicalistas, patrões e trabalhadores de Rio Formoso, assim como a partir de dados de observação e do conhecimento acumulado sobre a história das relações sociais nas grandes plantações da mata pernambucana. O caso foi objeto de uma referência em Sigaud (1996) e de uma primeira análise em Sigaud (1999a). A qui, retomo a reflexão de 1999 para dá-la a conhecer ao público de língua portuguesa, com o cuidado de refinar e ampliar a análise.

5 Sobre o processo usineiro, ver, entre outros títulos, Eisenberg (1977) e Correa de Andrade (1989).

6 As relações sociais estruturavam-se a partir da concessão de uma casa. Daí a designação relações de morada. A respeito das "regras da morada", ver Palmeira (1977b).

7 Os usineiros utilizavam o argumento da proteção social para atrair a mãode-obra, como se pode observar no caso da Usina Catende, a maior em Pernambuco na década de 40. Ver, a respeito, Catende (1941) e Sigaud (1993:27-28).

8 A partir das descrições das relações de morada, é possível afirmar que conformavam um modo de dominação a ser aproximado do tipo de dominação tradicional teorizado por $\mathrm{M}$ ax Weber, no que diz respeito à pessoalidade das relações, à garantia convencional e à crença no caráter sagrado da tradição. V er a respeito tanto os escritos de Weber sobre a ordem jurídica (1964:251-272) quanto sobre a sociologia da dominação (1964:753-809).

${ }^{9}$ A generosidade como valor e critério para aferição de prestígio aparece claramente nas memórias escritas pelos patrões (ver Bello 1985; Correa de Oliveira 1988; Nabuco 1995).

10 Os protestos que se desencadeiam na mata pernambucana são aqui interpretados como uma reação dos moradores às mudanças nas regras do jogo da dominação. Podem ser aproximados de outros protestos que também se originaram 
em rupturas de uma ordem tradicional, como os estudados por Thompson (1971), Hobsbawm e Rudé (1973) e Moore J r. (1967).

11 A criação de sindicatos de trabalhadores rurais acelera-se a partir de 1962, quando o M inistério do Trabalho regulamentou o decreto de sindicalização rural. Sobre os primeiros sindicatos então criados na zona da mata, ver Wilkie (1964).

12 Ver, a respeito, análise de Camargo (1981).

13 Sobre este primeiro acordo, cf. Callado (1964).

$14 \mathrm{O}$ arruado encontra-se no pátio do engenho. Designa a fileira de casas, muitas delas geminadas, onde residem os trabalhadores.

15 O roçado é a área utilizada para o plantio de produtos de ciclo curto, como milho e feijão. Distingue-se da roça, termo utilizado para designar área de plantio de mandioca e macaxeira.

16 Na Segunda Guerra Mundial, Bezerra prestou serviço militar e participou das patrulhas de vigilância na costa nordestina. Graças a esta atividade, possuía o estatuto de antigo combatente.

17 Para compreender as condições sociais que contribuíram para que os dirigentes sindicais investissem na regulação jurídica de conflitos, cf. Sigaud (1999b).

18 Botar questão é a expressão utilizada para nomear o ato de fazer uma reclamação na J ustiça. Questão é o termo que designa um conflito, um desentendimento.

19 Um dos dirigentes sindicais eleitos em 1965 conta que sua mãe se ajoeIhou, implorando a ele para que não entrasse para a diretoria do Sindicato. No engenho onde morava esse dirigente, três ativistas sindicais haviam sido torturados e assassinados pelos militares.

20 Em 1999, encontrei novamente Amaro Pedro e o entrevistei pela segunda vez. Ele não voltou a falar sobre o processo, mas acrescentou outros detal hes sobre sua relação com Bezerra e sobre os enfrentamentos com os patrões no pré-1964.

${ }^{21}$ Sobre as greves nas grandes plantações, ver Sigaud (1980; 1986).

$22 \mathrm{~N}$ os anos 80, fiz um censo dos processos trabalhistas na mata pernambucana e foi então que verifiquei a posição de Rio Formoso. Para mais elementos, cf. Sigaud (1999b). 
23 Um dos iniciados por Amaro Pedro foi J osé Francisco, irmão mais novo do antigo delegado sindical, Zé Chico, que chegou a Amaragi em 1978 oriundo de um município da zona canavieira onde o trabalho sindical era inexistente.

24 Sobre as ocupações de terra na mata pernambucana, cf. Sigaud (2000; 2003), Chamorro (2000) e Sigaud et alii (2001).

25 Sobre a crise em Amaragi, cf. Sigaud (1996) e Sigaud et alii (2001).

26 Sobre a saga de ocupações dos que saíram de Camaçari, ver Sigaud (2003) e www.lonasebandeiras.com.br.

27 M ovimento nesse contexto designa as organizações que promovem ocupações de terra. A ssim, o M ST, a Fetape, a Comissão Pastoral da Terra (CPT) são movimentos. Pernambuco é o estado da Federação com o maior número de movimentos. Sobre a lógica de criação desses movimentos, cf. Rosa (2004).

28 Desde 1993, conforme regulamentação do Congresso Nacional, a improdutividade das terras caracteriza o não cumprimento da função social da propriedade, situação em que a lei autoriza a desapropriação. Cabe ao INCRA avaliar a produtividade das terras e, quando constatada, a partir de critérios técnicos, a im produtividade, dar andamento ao processo de desapropriação.

29 Deste irmão Bezerra dizia que era “um homem bom”, mas que não sabia dar, o que indicava que não o considerava tão bom quanto ele. O esvaziamento do engenho seria um sinal dessa diferença.

30 Foram as obras de Norbert Elias, em particular seu estudo sobre M ozart (1991) e sobre a Alemanha (1996), que chamaram a minha atenção para a importância de se levar em conta o que, do ponto de vista dos indivíduos, confere sentido à sua vida, quando se trata de interpretar suas condutas.

31 É o que se pode constatar, a partir dos trabalhos de N ovaes (1997) sobre a Paraíba e de Heredia (1988) sobre Alagoas. 


\section{Referências bibliográficas}

BELLO, J ulio. 1985 [1938]. Memórias de um senhor de engenho. Recife: Fundape.

CALLADO, Antonio. 1964. Tempo de Arraes. Rio de J aneiro: J osé Álvaro Editora.

CAMARGO, Aspásia. 1981. “A questão agrária: crise de poder e reformas de base (1930-1964)". In: B. Fausto (org.), História geral da civilização brasileira, tomo 3, vol. 3. São Paulo: Difel. pp. 121-224.

CATENDE (ed.). 1941. O homem e a terra na Usina Catende. Recife: Usina Catende.

CHAM ORRO, Sergio. 2000. Com a cara e a coragem. Uma etnografia de uma ocupação de terras. Dissertação de Mestrado, Museu Nacional/PPGAS/ UFRJ .

CORREA DE ANDRADE, M anuel. 1989. História das usinas de açúcar de Pernambuco. Recife: Editora Massangana.

CORREA DE OLIVEIRA, J oão Alfredo. 1988. M inha meninice \& outros ensaios. Recife: Fundação J oaquim Nabuco/Editora Massangana.

DUBY, George. 1984. Guillaume le Marechal ou le meilleur chevalier du monde. Paris: Fayard.

EISENBERG, Peter L. 1977. M odernização sem mudança. A indústria açucareira em Pernambuco: 1840/1910. Rio de J aneiro/Campinas, SP: Paz e Terra/Unicamp.

ELIAS, N orbert. 1991. The established and the outsiders. London: Sage Publications.

. 1996. The Germans. Power struggles and the development of habitus in the nineteenth and twentieth centuries. Cambridge, U.K.: Polity Press.
FURTADO, Celso. 1964. A dialética do desenvolvimento. Rio de J aneiro: Editora Fundo de Cultura.

HEREDIA, Beatriz. 1988. Formas de dominação e espaço social. A modernização da agro-indústria açucareira em Alagoas. São Paulo: Ed. Marco Zero.

HOBSBAWM, Eric e RUDÉ, George. 1973 [1969]. Captain Swing. London: Penguin University Books.

LEACH, Edmund. 1961 [1945]. “J inghpaw kinship terminology: an experiment in ethnographic algebra". In: Rethinking anthropology. London: Athlone Press. pp. 28-53.

MALIN OWSKI, Bronislaw. 1970 [1926]. Crime and custom in savage society. London: Routledge and Keagan Paul.

MAUSS, Marcel. 1991 [1923-24]. “Essai sur le don: forme et raison de l'échange dans les sociétés archaiques". In: Sociologie et anthropologie. Paris: PUF. pp. 143-279.

MOORE J R., Barrington. 1967. Social origins of democracy and dictatorship. Boston: Beacon Press.

NABUCO, J oaquim. 1995 [1900]. Minha formação. Porto Alegre: Editora Paraula.

NOVAES, Regina. 1997. De corpo e alma. Catolicismo, classes sociais e conflitos no campo. Rio de J aneiro: Graphia.

PALMEIRA, M oacir. 1977a. “The aftermath of peasant mobilization: rural conflicts in the Brazilian Northeast since 1964". In: N. Aguiar (org.), The structure of Brazilian development. N ew York: Transaction Books. . 1977b. "Casa e trabalho: notas sobre as relações sociais na plantation 
tradicional". Contraponto, 2:103114.

ROSA, M arcelo Carvalho. 2004. O engenho dos movimentos. Reforma agrária e significação social na zona canavieira de Pernambuco. Tese de Doutorado, IUPERJ, Rio de J aneiro.

SIGAUD, Lygia. 1980. Greve no engenho. Rio de J aneiro: Paz e Terra. . 1986. "A luta de classes em dois atos: notas sobre um ciclo de greves camponesas". Dados, 29(3):319334.

1993. “Des plantations aux villes: les ambigüités d'un choix". Études Rurales, 131-132:19-37.

_ . 1996. “Le courage, la peur et la honte. Morale et économie dans les plantations sucrières du Nordeste brésilien". Genèses. Sciences Sociales et Histoire, 25:72-90.

. 1999a. “H onneur et tradition dans les plantations sucrières du Nordeste (Brésil)". Études Rurales, 149150:211-228.

. 1999b. “Les paysans et le droit: le mode juridique de règlement de conflits". I nformations sur les Sciences Sociales, 38(1):113-147.

. 2000. “A forma acampamento: notas a partir da versão pernambucana". Novos Estudos CEBRAP, 58: 73-92.

. 2003. Lonas e bandeiras em terras pernambucanas (catálogo da exposição de mesmo nome). Rio de J aneiro: Museu Nacional.

et alii. 2001. "Histoires de campements". Cahiers du Brésil Contemporain, 43/44:31-70.

THOMPSON, E. P. 1971. “The moral economy of the English crowd in the $18^{\text {th }}$ century". Past and Present, 50:76-136.

WEBER, Max. 1964. Economía y sociedad, M éxico: Fondo de Cultura Económica.
1965 [1913]. “Essai sur quelques catégories de la sociologie compréhensive". In: Essais sur la théorie de la science. Paris: Plon. pp. 325-398.

WILKIE, Mary E. 1964. A report on rural syndicates in Pernambuco. Centro Latino-Americano de Pesquisas em Ciências Sociais. Manuscrito. 16 pp. 


\section{Resumo}

Este artigo focaliza uma queixa judicial de um trabalhador contra um patrão, ocorrida em 1965, na mata sul pernambucana, a qual apresentava características excepcionais em relação à norma dos processos naquela região das grandes plantações canavieiras. $\mathrm{Na}$ primeira parte, reconstitui as condições sociais nas quais se produziu o caso, examina os sentidos das condutas dos atores na sucessão dos eventos, identifica as coerções que se abateram sobre eles e explora as implicações do acontecimento. $\mathrm{Na}$ segunda parte, focaliza a história das relações sociais na plantação no período subseqüente, tendo como eixo o direito, seus usos e sua eficácia. A análise permite melhor compreender a dinâmica e a complexidade dos processos que contribuem para que os indivíduos passem a agir levando em conta a existência de normas jurídicas.

Palavras-chave Direito; Troca; TrabaIhadore rurais; N ordeste

\section{Abstract}

This article focuses on a lawsuit filed by a worker against his boss, in 1965, in the southern Pernambuco countryside. This case proved to be exceptional compared to the normal run of legal processes in this region of large-scale sugarcane plantations. The first part reconstructs the social conditions in which the case took shape, examining the meanings behind the behaviour of actors in the unfolding events, and identifying the forms of coercion placed upon them. I also explore the implications of the case. The second part concentrates on the history of social relations in the plantation during the subsequent period, seen in terms of the law - its uses and its effectiveness. The analysis enables a clearer understanding of the dynamics and complexity of some of the processes causing individuals to start to act in response to legal norms.

Key words Law; Exchange; Rural workers; $N$ ortheast Brazil 